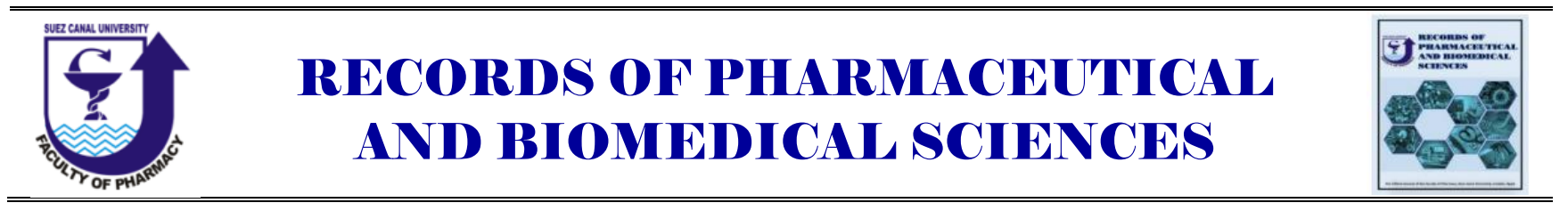

\title{
Phytochemistry and Pharmacological Effects of Plants in Genus Sonchus (Asteraceae)
}

\author{
Heba Fouad, Eman S. Habib, Safwat A.Ahmed* \\ Pharmacognosy Department, Faculty of Pharmacy, Suez Canal University, Ismailia, Egypt
}

Received on: 05. 11. 2019

Revised on: 26. 12. 2019

Accepted on: 11.01. 2020

Correspondence Author:

Tel: +01092638387

E-mail address:

safwat_aa@yahoo.com

\begin{abstract}
Medicinal plants have been used since ancient times for treatment of various diseases. Many of the drugs available on the market today originated either directly or indirectly from bioactive compounds isolated from plants. Family Asteraceae is one of the largest families of flowering plants, comprising 1600 genera and almost 30000 species worldwide (Bisht et al., 2010). The genus Sonchus is a genus of flowering plants in the dandelion tribe of the Asteraceae Family. It consists mostly of annual herbs, but a few are perennial or woody herbs. Annual herbs, known as sow thistles, were used as food stock for animals, particularly for rabbits. They are also edible to humans as a leafy vegetable. In Chinese folk medicine, sow thistles have been used for the treatment of fever, inflammation, for detoxication and improvement of blood circulation. Recent advances in the ethnomedicinal, phytochemical, and pharmacological studies of this genus are reviewed in this paper (Muhammed et .,al 2012 ). Results showed that secondary metabolites isolated and identified from genus Sonchus were mainly terpenes, sterols, flavonoids, and coumarins. In vivo and in vitro pharmacological studies have shown that plants belonging to this genus exhibit various biological activities, including antioxidant, anti-inflammatory, antibacterial, antidepressant, anxiolytic, and anti-tumor activities (Jain et al., 2014). Further attention should be given to the study of species belonging to genus Sonchus especially regarding toxicological effects. Further research on Sonchus plants should be conducted using bioactivity-guided isolation strategies to isolate and identify the bioactive metabolites in this genus.
\end{abstract}

Keywords: Sonchus, secondary metabolites, Asteraceae.

\section{Introduction}

Since ancient times, people have turned to natural sources, mainly plants, for production of foods, clothing, fragrances, flavors and medicines (Gurib-Fakim, 2006). In recent years, a renewed interest in obtaining biologically active compounds from natural sources has been observed. Reasons for this worldwide attention towards formulations based on natural products include their low toxicity, their complete biodegradability, their availability from renewable sources, and in most cases, their low cost compared to synthetic compounds. Phytochemical investigation of plants has led to the discovery of novel secondary metabolites, which were used as leads for therapeutic agents (Savithramma et al., 2011). Family Asteraceae, previously known as Compositae, is also known as the daisy family, sunflower family or thistle family. It is one of the largest families of flowering plants, 
including almost 30000 species and 1600 - 1700 genera worldwide, and inhabits almost every environment. The name Asteraceae comes from the term Aster meaning star and refers to the characteristic flower heads composed of many small flowers, called florets, surrounded by bracts. Asteraceae plants are most common in the moderate regions and hot mountains. (Bisht et al., 2010).

The genus Sonchus is a genus of the Asteraceae Family that belongs to the dandelion tribe. It consists mostly of annual herbs, but a few are perennial or woody herbs, such as subgenus Dendrosonchus which grows in the Canary Islands. Annual herbs in the genus are known as sow thistles, because they were fed to lactating sows and believed to increase milk production. They are characterized by soft, irregularly lobed leaves that clasp the stem and sometimes form a basal rosette. The stem can range from $30 \mathrm{~cm}$ to $2 \mathrm{~m}$ (1 to 6 feet) in height and contains a milky latex. Flower heads are yellow, half to one inch in diameter; the florets are all of ray type. Sow thistles are common roadside plants that are native to Eurasia and tropical Africa, but they are found almost worldwide in temperate regions. Sow thistles are considered noxious weeds, as they grow quickly and spread rapidly in a wide range of conditions.

Sow thistles have been used as food for livestock, hence sometimes known by the common name "hare thistle" or "hare lettuce". They are also edible to humans as leafy vegetables, commonly consumed in Mediterranean countries. It is very important in the diets of urban people and provides a relatively inexpensive vegetable to the society (Vilala, 2009). In China, sow thistles have been used in folk medicine for the treatment of fever, inflammation, for detoxication and improvement of blood circulation (Muhammad et al., 2012). Phytochemical investigation of plants belonging to genus Sonchus has showed that they contain several classes of secondary metabolites, including terpenes, sterols, flavonoids, and coumarins. Pharmacological studies conducted on the plant extracts and isolated compounds have shown that the plant has various medicinal uses including antioxidant, anti-inflammatory, antitumor, antibacterial, antidepressant, emollient, blood purifying and liver tonic activities (Jain et al., 2014).

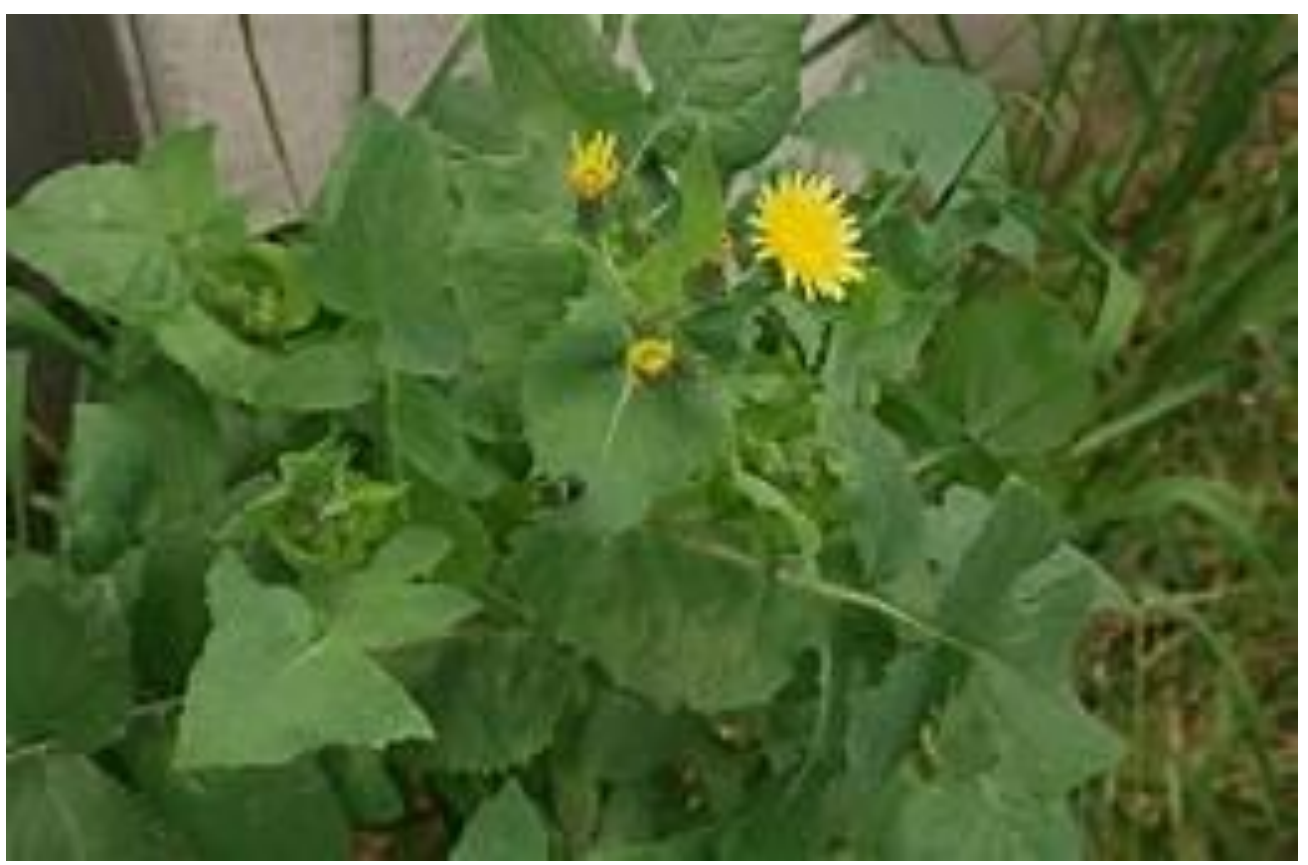

Fig. (1): Sonchus oleraceus herb. 
2. Chemical constituents reported from some species of genus Sonchus:

\subsection{Flavonoids:}<smiles>[R6]c1cc([R6])c2c(=O)c([R3])c(-c3cc([R8])c([R6])c([R3])c3[R])oc2c1</smiles>

\begin{tabular}{|c|c|c|c|c|c|c|c|c|c|}
\hline Species & Name & $\mathbf{R}_{1}$ & $\mathbf{R}_{2}$ & $\mathbf{R}_{\mathbf{3}}$ & $\mathbf{R}_{\mathbf{4}}$ & $\mathbf{R}_{5}$ & $\mathbf{R}_{\mathbf{6}}$ & $\mathbf{R}_{7}$ & Reference \\
\hline S.oleraceus & Luteolin & $\mathrm{OH}$ & $\mathrm{OH}$ & $\mathrm{H}$ & $\mathrm{H}$ & $\mathrm{H}$ & $\mathrm{OH}$ & $\mathrm{OH}$ & $\begin{array}{l}\text { (Bondarenko et } \\
\text { al.,1973) }\end{array}$ \\
\hline S.oleraceus & $\begin{array}{l}\text { Luteolin-7-O- } \\
\text { glucoside }\end{array}$ & $\mathrm{OH}$ & $\mathrm{OH}$ & $\mathrm{H}$ & $\mathrm{H}$ & $\mathrm{H}$ & $\mathrm{OH}$ & $O$-Gluc. & $\begin{array}{l}\text { (Bondarenko et } \\
\text { al.,1973) }\end{array}$ \\
\hline S.arvensis & Isocinaroside & $\mathrm{OH}$ & $\mathrm{OH}$ & $\mathrm{H}$ & $\mathrm{H}$ & $\mathrm{H}$ & $\mathrm{H}$ & $O$-Gluc. & $\begin{array}{l}\text { (Bondarenko et } \\
\text { al.,1974) }\end{array}$ \\
\hline S. arvensis & Linarin & $\mathrm{H}$ & $\mathrm{OCH} 3$ & $\mathrm{H}$ & $\mathrm{H}$ & $\mathrm{H}$ & $\mathrm{H}$ & $\begin{array}{c}O- \\
\text { Rutinosi } \\
\text { de }\end{array}$ & $\begin{array}{l}\text { (Bondarenko et } \\
\text { al.,1975) }\end{array}$ \\
\hline S.arvensis & Isorhamnetin & $\mathrm{OH}$ & $\mathrm{OCH} 3$ & $\mathrm{H}$ & $\mathrm{H}$ & $\mathrm{OH}$ & $\mathrm{OH}$ & $\mathrm{OH}$ & $\begin{array}{l}\text { (Bondarenko et } \\
\text { al.,1976) }\end{array}$ \\
\hline S.arvensis & Quercetin & $\mathrm{OH}$ & $\mathrm{OH}$ & $\mathrm{H}$ & $\mathrm{H}$ & $\mathrm{OH}$ & $\mathrm{OH}$ & $\mathrm{OH}$ & $\begin{array}{l}\text { (Bondarenko et } \\
\text { al.,1976) }\end{array}$ \\
\hline S.arvensis & Soncoside & $\mathrm{OH}$ & $\mathrm{OH}$ & $\mathrm{H}$ & $\mathrm{OH}$ & $\mathrm{H}$ & $\mathrm{OH}$ & $O$-Gluc & $\begin{array}{l}\text { (Bondarenko et } \\
\text { al.,1978) }\end{array}$ \\
\hline S.arvensis & Apigenin & $\mathrm{H}$ & $\mathrm{OH}$ & $\mathrm{H}$ & $\mathrm{H}$ & $\mathrm{H}$ & $\mathrm{OH}$ & $\mathrm{OH}$ & $\begin{array}{l}\text { (Qu Guirong et } \\
\text { al.,1993) }\end{array}$ \\
\hline $\begin{array}{l}\text { S.oleraceus } \\
\text { S.asper } \\
\text { S.maritimus }\end{array}$ & $\begin{array}{l}\text { Apigenin-7- } \\
\text { glucoside }\end{array}$ & $\mathrm{H}$ & $\mathrm{OH}$ & $\mathrm{H}$ & $\mathrm{H}$ & $\mathrm{H}$ & $\mathrm{OH}$ & $O$-Glu & (Giner et al.,1993) \\
\hline
\end{tabular}


Rec. Pharm. Biomed. Sci. 4 (1), 40- 50, 2020

\subsection{Terpenoids:}

Plant species Compound name
S.macrocarpus $\begin{aligned} & \text { 15-hydroxy4- } \beta, 15- \\ & \text { dihydroreynosin } \\ & \text { sonchucarpolide }\end{aligned}$
15-hydroxy-4 $\beta, 15,11 \beta, 13-$
tetrahydroreynosin

Sonchuside E

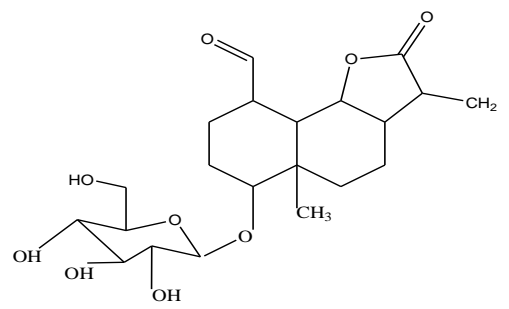

Sonchuside $\mathrm{H}$

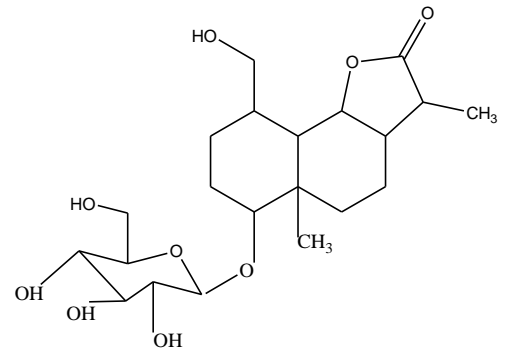

(Shimizu et al.,1989)

Sonchuside G

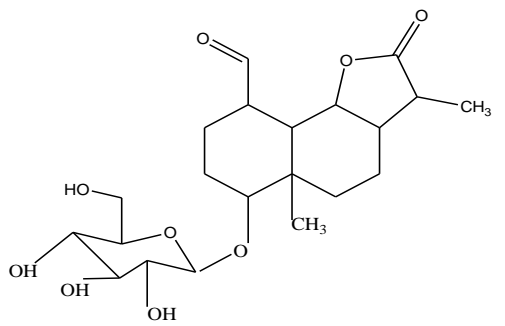


Sonchuside F

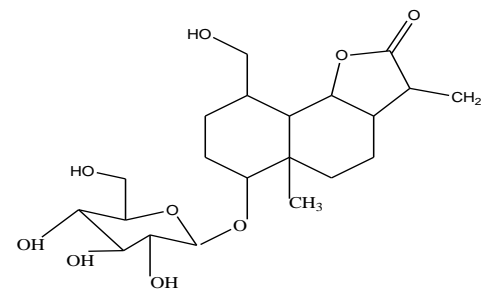

Sonchuside I

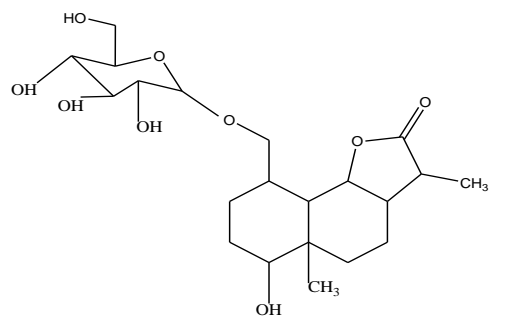

(1 $\beta, 6 \alpha)$-1,6-dihydroxy-14-O[(4hydroxyphenyl)acetyl]eudesma3,11(13)-dien-12-oic acid $\gamma$ lactone

S. uliginosus

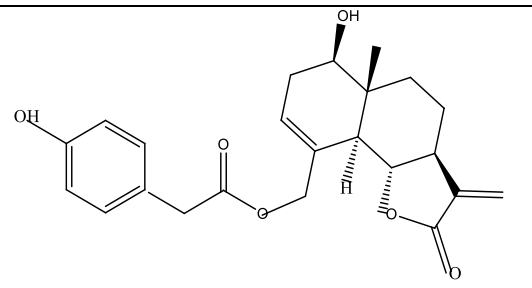

$(1 \beta, 6 \alpha)-1,6,14-$

trihydroxyeudesma-3,11(13)-dien12-oic acid $\gamma$ - lactone

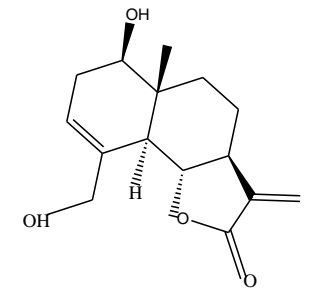

(Zhang et al .,2006)

loliolide

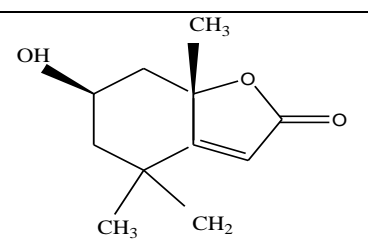

S. oleraceus lupeol

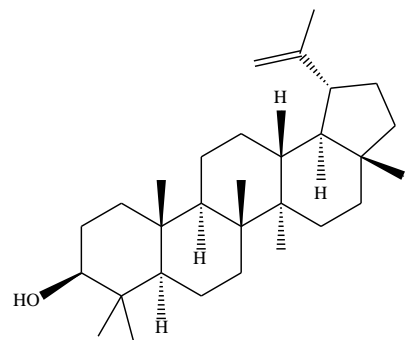

(Saad.E.,2009)

13-(p-hydroxyphenylacetyl)-15-

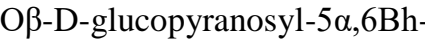
eudesma-3-en-12,6 $\alpha$-olide

\section{S. arvensise}

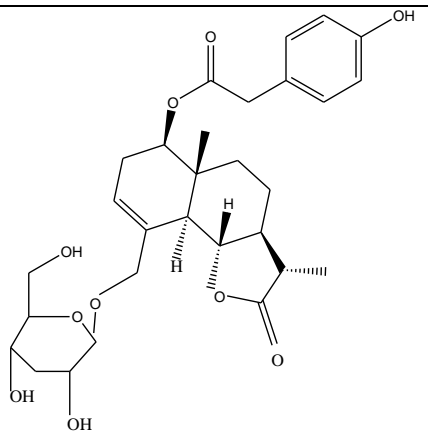

(Xia et al.,2010) 
Rec. Pharm. Biomed. Sci. 4 (1), 40- 50, 2020

$1 \beta$-sulfate- $5 \alpha, 6 \beta \mathrm{H}$-eudesma-3-en12,6 $\alpha$-olide

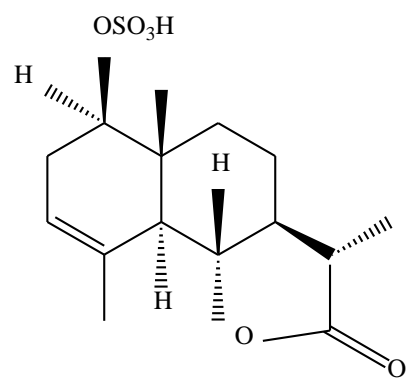

\subsection{Organic acids:}

Plant species

Caffeic acid

S.glaucescens

S.oleraceus

S. maritimus

S.asper

S.glaucescens

S.oleraceus

S.tenerrimus

Chlorogenic acid<smiles>O=C(/C=C/c1ccc(O)c(O)c1)OC1=C(O)C(O)=CC(O)(C(=O)O)C1</smiles>

$\mathrm{OH}$<smiles>O=C(O)/C=C/c1ccc(O)c(O)c1</smiles>

(Giner et al ., 1993)

(Giner et al ., 1993)

S. oleraceus

Caftaric acid<smiles>O=C(O)C(O)C(O)C(=O)/C=C/c1ccc(O)c(O)c1</smiles>

(Ou et al .,2012)<smiles>O=C(/C=C/c1ccc(O)c(O)c1)O[C@H](C(=O)O)[C@@H](OC(=O)/C=C/c1ccc(O)c(O)c1)C(=O)O</smiles> 


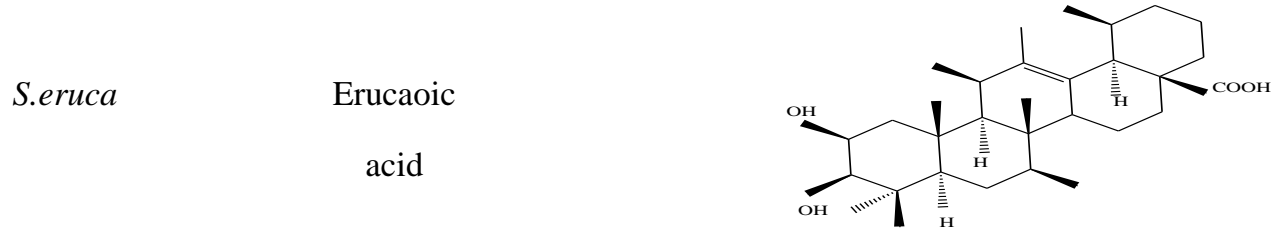

(Muhammad

et al.,2012)

\subsection{Fatty acids:}

Plant species

Compound name

Compound structure

References

Myristic acid<smiles>CCCCCCCCCCCCCC(=O)O</smiles>

S.arvensise

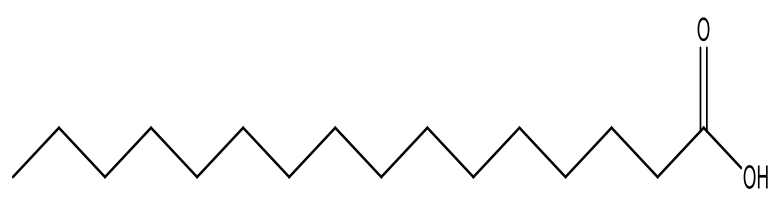

(Shukla et

Palmitic acid

Linoleic acid

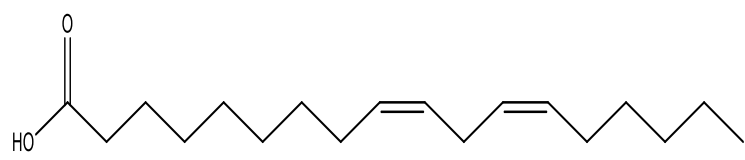

\subsection{Miscellaneous compounds:}

\subsubsection{Coumarins:}

Cichoriin has been detected in Sonchus asper, Sonchus glaucescens and Sonchus tenerrimus. Aesculetin has been detected in Sonchus asper and Sonchus glaucescens, (Giner et al., 1993).<smiles>O=c1ccc2cc(O)c(O)cc2o1</smiles><smiles>O=C1CCc2cc(O)c(OC3OC(CO)C(O)C(O)C3O)cc2O1</smiles>

Cichoriin Aesculetin

\subsubsection{Esters}


Quinic acid ester was identified from Sonchus arvensis (Xu et al., 2008)<smiles>COC(=O)C1(O)CC(O)C(O)C(O)C1</smiles>

3, 4, 5-tri-(p-hydroxyphenylacetyl)<smiles>[R]C(=O)Cc1ccc(O)cc1</smiles>

quinic acid methyl ester

Hexadecanoic methyl ester was identified from Sonchus wightianus (Joshi et al., 2011).<smiles>CCCCCCCCCCCCCCCC(=O)OC</smiles>

\subsubsection{Ionone glycosides}

These were isolated from Sonchus erzincanicus

Corchoionoside C 6-O-sulfate (Ozgen et al, 2010).

Corchoionoside (Ozgen et al, 2010).
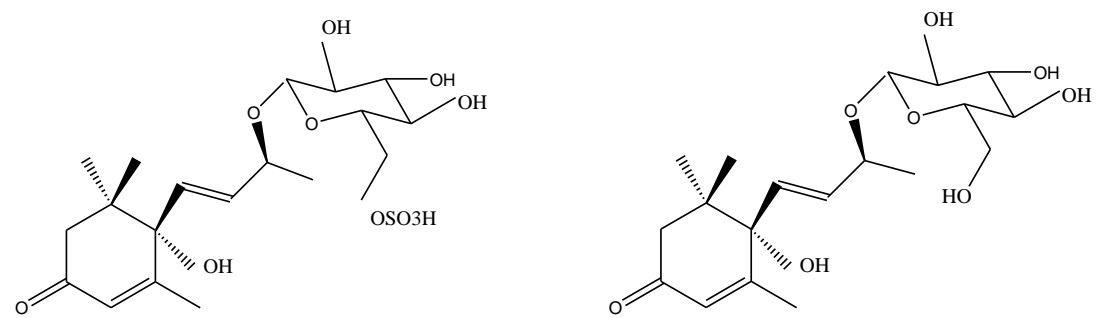

\section{Biological activities of some species of genus Sonchus:}

\subsection{Antioxidant activity:}

In a study by Khan et al., Sonchus asper extracts exhibited a remarkable capacity to scavenge all the tested reactive species with $\mathrm{IC}_{50}$ values at the $\mu \mathrm{g} /$ $\mathrm{ml}$ level. The methanolic extract showed the best activities in scavenging of superoxide radicals and hydrogen peroxide as well as hydroxyl radicals. In addition, S.arvensis extract was found to possess free radical- scavenging properties which might be due to the presence of polyphenolic constituent (Khan et al., 2012). Using the CAA assay, it was shown that foliar extracts of Sonchus oleraceus were effectively absorbed into HepG2 cells, and exerted antioxidant activity at levels comparable to those of extracts from blueberry. (McDowell et al., 2011). Another study that investigated the antioxidant activity of Sonchus oleraceus L.in vitro was performed by Yin and his coworkers, and the results suggested that $S$. oleraceus extract could be used as a potential source of natural antioxidants (Yin et al., 2007). Sonchus arvensis extract exhibited the highest radical scavenging power and 
lipid peroxidation inhibitory power among a number os tested extracts (Xia et al., 2011).

\subsection{Anti-inflammatory effect:}

In a study by $\mathrm{Li}$ et al. the extract of Sonchus oleraceus had significant anti-inflammatory effects in vivo at the concentration of 250 and $125 \mathrm{mg} / \mathrm{kg}$. (Li et al., 2017). In 2010, a study showed that Sonchus oleraceus extract exhibited antiinflammatory effects by reducing paw edema brought by carrageenan. The extract administered at $300 \mathrm{mg} / \mathrm{kg}$ had a powerful anti-inflammatory effect compared to indomethacin at a dose of $(10 \mathrm{mg} / \mathrm{kg})$ (Vilela et al., 2010).

\subsection{Anti- nociceptive activity:}

The extract of Sonchus oleraceus produced significant inhibition of chemical nociception induced by intraperitoneal acetic acid and subplantar formalin. (Vilela et al., 2009).

\subsection{Anti-Ageing effect:}

At a dose of 5 and $20 \mathrm{mg} / \mathrm{mL}$, S. oleraceus extracts showed significant reduction of stress-induced premature senescence compared to ascorbic acid treatments, and was recommended for use as an anti-ageing agent (Ou et al., 2015).

\subsection{Anxiolytic like effect:}

The extracts of Sonchus oleraceus administered at $30-300 \mathrm{mg} / \mathrm{kg}$, had a similar anxiolytic effect to clonazepam $(0.5 \mathrm{mg} / \mathrm{kg})$ (Vilela et al., 2009).

\subsection{Hepatoprotective activity:}

Liver histopathology showed that Sonchus asper extract reduced the incidence of hepatic lesions induced by $\mathrm{CCl}_{4}$ in rats (Khan et al., 2012).

\subsection{Antidepressant activity:}

The active principles present in the extract of Sonchus oleraceus had an antidepressant like effect which was found to be comparable to that of amitriptyline. Therefore, the authors concluded that a standardized $S$. oleraceus extract or its pure active constituents could be of possible interest for the treatment of depressive disorders (Vilela et al., 2010).

\subsection{Antibacterial activity:}

Xia et al. investigated the antibacterial activity of six Sonchus extracts. Sonchus oleraceus extract showed higher antibacterial activity than the other five Sonchus extracts (S. arvensis, S.asper, $S$. uliginosus, $S$. brachyotus and $S$. lingianus), both in Gram-negative bacteria (Escherichia coli, Salmonella enterica and Vibrio parahaemolyticus) and in a Gram-positive bacterium (Staphylococcus aureus) (Xia et al.,2011).

\subsection{Antitumor activity:}

Yin et al. reported that hot aqueous extract of Sonchus oleraceus had inhibitory effects on the liver cancer cell line HepG-2 and K562 cells by decreasing cell sustainability and prompting apoptosis which could block the tumor cell cycle (Yin et al., 2007). Ibrahim et al. investigated the cytotoxicity of Sonchus oleraceus and S. asper extracts. S. oleraceus showed a moderate inhibition of Hep-G2 and HCT-116 cells, while S. asper showed low inhibition against all cells (Hep-G, HCT-116 and MCF-7) (Ibrahim et al., 2015). In 2010, a study was designed to evaluate the cytotoxic effect of the ethanolic, cold aqueous and hot aqueous extracts of $S$. oleraceus on three cancer cell lines (AMN-3), (Hep-2) and (REF) as normal cell line. The cytotoxic effect of both cold and hot aqueous extracts on AMN-3 and Hep- 2 cell lines was higher than that of the ethanolic extract (Zghair et al., 2010).

\section{Conclusion:}

The genus Sonchus is rich in secondary metabolites that belong to various classes such as flavonoids, terpenes, fatty acids and coumarins. Plants of genus Sonchus have various biological activities including antioxidant, anti-inflammatory, antidepressant, anxiolytic and antitumor activities. In this review, we covered the secondary metabolites isolated from plants belonging to the genus Sonchus, in addition to the various pharmacological studies on the biological activities of Sonchus species. 


\section{References}

Bisht, V., K., Purohit, V. 2010. Medicinal and aromatic plants diversity of Asteraceae in Uttarakhand. Nature and Science. (3):121-128.

Bondarenko, V. G., Glyzin, V. 1, Shelyuto, V. L. 1973 Flavonoids of the flowers of Sonchus arvensis L. Chemistry of Natural Compounds. 9:522.

Bondarenko, V. G., Glyzin V. I., Ban'kovskii,A.I, Shelyuto, V. L. 1974 Isocynaroside, a new flavone glycoside. Chemistry of Natural Compounds. 10:680.

Bondarenko, V. G., Glyzin V. I, Shelyuto, V. L., Smirnova, L. P. 1976. Flavonoids of Sonchus arvensis. Chemistry of Natural Compounds.12:484.

Bondarenko, V. G., Glyzin, V. I, Shelyuto, V. L. 1978. Sonchoside - a new flavonoid glycoside from Sonchus arvensis. Chemistry of Natural Compounds.14:340.

Bondarenko, V. G., Glyzin, V. I., Shelyuto, V. L. 1983. Flavonoids of the flowers of Sonchus oleraceus. Chemistry of Natural Compounds. 19:228.

Giner, R.M., Ubeda, A., Just, M.J., Serrano, A., Manez, S., Rios,J. 1993. A chemotaxonomic survey of Sonchus Subgenus Sonchus.Biochemical systemics and Ecology. 21(5):617-620.

Guirong, Q., Xin, L., Jain, L. 1996. Studies on flavone glycosides of Sonchus arvensis. China journal. 21(5):292-294.

Gurib-Fakim, A. 2006. Medicinal plants, traditions of yesterday and drugs of tomorrow. Molecular aspects of Medicine. 27(1): 1-93.

Jain, S.K., Singh, G.K. 2014. Prelminary phytochemical screening and in vitro antioxidant activity of extracts of whole plant of Sonchus oleraceus Asteraceae .journal of pharmaceutical science. (3):1-12.

Joshi, S., Poudel, T. N. 2013. Isolation and characterization of the chemical constituents of Sonchus wightianus of Nepalese origin. Journal of Nepal Chemical Society. 28:115-120.

Ibrahim, F., Abed El-Azim, M., Mohamed, A., Kollab, K. 2015. Chemical and biological evaluation of the diethyl ether extract of wild Sonchus asper and Sonchus oleraceus growing in

Vilela, F. C., de Mesquita Padilha, M., dos Santos-
Libya. International Journal of Pharmaceuticals 5(3):693-70.

Khan, R. A., Khan, M. R., Sahreen, S., Ahmed, M. 2012. Evaluation of phenolic contents and antioxidant activity of various solvent extracts of Sonchus asper (L.) Hill. Chemistry Central Journal. 6(1): 12.

Khan, R. A. (2012). Evaluation of flavonoids and diverse antioxidant activities of Sonchus arvensis. Chemistry Central Journal. 6(1): 126.

Khan, R. A., Khan, M. R., Sahreen, S., Shah, N. A. 2012. Hepatoprotective activity of Sonchus asper against carbon tetrachloride-induced injuries in male rats, a randomized controlled trial. Complementary and Alternative medicine. 12(1): 90.

Li, Q., Dong, D. D., Huang, Q. P., Li, J., Du, Y. Y., Li, B., Huyan, T. 2017. The anti-inflammatory effect of Sonchus oleraceus aqueous extract on lipopolysaccharide stimulated RAW 264.7 cells and mice. Pharmaceutical biology. 55(1):799-809.

Muhammad, Z., Ahmad, S., Ullah, R., Ullah, F., Jan, S. 2012. Isolation and characterization of two new compounds from genus Sonchus. Biomedical and Pharmacology Journal. 5(1):65-70.

McDowell, A., Thompson, S., Stark, M., Ou, Z. Q., Gould, K. S. 2011. Antioxidant activity of puha (Sonchus oleraceus L.) as assessed by the cellular antioxidant activity (CAA) assay. Phytotherapy Research. 25(12): 1876-1882.

Ou, Z. Q., Schmierer, D. M., Rades, T., Larsen, L., McDowell, A. 2012. Application of an online postcolumn derivatization HPLC-DPPH assay to detect compounds responsible for antioxidant activity in Sonchus oleraceus $L$. leaf extracts. Journal of Pharmacy and Pharmacology. 65(2): 271-279.

Ou, Z. Q., Rades, T., McDowell, A. (2015). AntiAgeing Effects of Sonchus oleraceus L. (pūhā) leaf extracts on $\mathrm{H}_{2} \mathrm{O}_{2}$-induced cell senescence. Molecules. 20(3): 4548-4564.

Ozgen, U., Sevindik, H., Kazaz, C., Yigit, D., Kandemir, A., Secen, H., Calis, I. 2010. A new sulfated $\alpha$-ionone glycoside from Sonchus erzincanicus Matthews. Molecules. 15(4):25932599.

Savithramma, N., Lingarao, M., Suhrwlatha,D. 
2011. Screening of medicinal plants for secondary metabolites. Middle East Journal of Scientific Research. (3):579-584.

e-Silva, L., Alves-da-Silva, G., Giusti-Paiva, A. 2009. Evaluation of the antinociceptive activity of extracts of Sonchus oleraceus L. in mice. Journal of Ethnopharmacology. 124(2): 306-310.

Vilela, F., C., Soncini, R., Ginsti, A.L. 2009. Anxiolytic like effect of Sonchus oleraceusL. in mice.journal of Ethenopharmacology. (2):325-327.

Vilela, F. C., de Mesquita Padilha, M., Alves-DaSilva, G., Soncini, R., Giusti-Paiva, A. 2010. Antidepressant-like activity of Sonchus oleraceus in mouse models of immobility tests. Journal of medicinal food. 13(1): 219-222.

Vilela, F. C., Bitencourt, A. D., Cabral, L. D., Franqui, L. S., Soncini, R., Giusti-Paiva, A. 2010. Anti-inflammatory and antipyretic effects of Sonchus oleraceus in rats. Journal of ethnopharmacology. 127(3): 737-741.
Xia, Z., Qu, W., Lu, H., Fu, J., Ren, Y., Liang, J. 2010. Sesquiterpene lactones from Sonchus arvensis $L$. and their antibacterial activity against Streptococcus mutans ATCC 25175. Fitoterapia. 81(5): 424-428.

Xia, D. Z., Yu, X. F., Zhu, Z. Y., Zou, Z. D. 2011. Antioxidant and antibacterial activity of six edible wild plants (Sonchus spp.) in China. Natural product research. 25(20): 1893-1901.

Yin, J., SI., CH., Wang. 2007. Antioxidant activity of flavonoids and their glycosides from Sonchus Oleraceus L. Nutrition research and Practice. 51(2):57-60.

Yin, J., Kwon, G. J., Wang, M. H. 2007. The antioxidant and cytotoxic activities of Sonchus oleraceus $L$. extracts. Nutrition research and Practice. 1(3): 189-194.

Zghair, Z. R., Yaseen, N. Y., Makkawi, T. A. 2010. The effect of crude extracts of Sonchus oleraceus on cancer cell growth (in vitro). Iraqi Journal of Veterinary Sciences. 34: 30-38. 